\section{Total Intravenous Anesthesia with Target-Controlled Infusion of Remifetanil and Propofol for Ablation of Atrial Fibrillation}

Fernando Squeff Nora, TSA ${ }^{1}$, Maurício Pimentel ${ }^{2}$, Leandro loschpe Zimerman ${ }^{3}$, Eduardo B. Saad ${ }^{4}$

\section{INTRODUCTION}

Ablation of atrial fibrillation $(\mathrm{AF})$ is a relatively new procedure among us, although it is common in other centers. The choice of anesthesia, monitors, and anesthetic care for this procedure performed outside the surgical center has not been described. The objective of this report was to describe an anesthesia technique for ablation of AF as well as to present a brief review on the safety of the anesthetics used since some of them can change electrical conduction in the normal heart and anomalous conduction pathways, hindering the procedure and the evaluation of its efficacy.

\section{CASE REPORT}

This is a 49-year old female weighing $73 \mathrm{~kg}$, height $155 \mathrm{~cm}$, and ASA II due to hypertension. The patient was premedicated with oral midazolam $15 \mathrm{mg}$ that was also used for sedation during the transesophageal echocardiogram to confirm the absence of intracavitary thrombi. In the hemodynamics room, a 16G Teflon catheter was used for peripheral venoclysis under local anesthesia with $1 \%$ lidocaine without epinephrine, and a $20 \mathrm{G}$ catheter was used for arterial puncture for invasive blood pressure determinations (MAP). Monitoring consisted of a 12-lead electrocardiogram, pulse oximetry, heart rate, bispectral electroencephalography to measure BIS, suppression rate (SR), and SEF 95, and MAP. Anesthesia was induced with intravenous target-controlled infusion (TCl) of propofol with a target of $4 \mu \mathrm{g} \cdot \mathrm{mL}^{-1}$, intravenous IAC of remifentanil with a target of $3 \mathrm{ng} \cdot \mathrm{mL}^{-1}$, and intravenous bolus of rocuronium $0.2 \mathrm{mg} \cdot \mathrm{kg}^{-1}$. Shortly before induction, the patient was oxygenated, intubated, and placed on volume controlled mechanical ventilation to maintain $\mathrm{P}_{\mathrm{ET}} \mathrm{CO}_{2}$ between 30 and $35 \mathrm{~mm} \mathrm{Hg}$. Verbal contacted was maintained during induction to detect the moment of loss of verbal response. Verbal response was lost when the concentration of propofol at the effector site reached 0.7 $\mu \mathrm{g} \cdot \mathrm{mL}^{-1}$ and of remifentanil $2 \mathrm{ng} \cdot \mathrm{mL}^{-1}$. The bispectral index at this moment was 70 and SEF95 $=22$, and the patient was ventilated with a face mask until further reduction of BIS was detected. Tracheal intubation was performed when the concentration of propofol at the effector site reached $2.2 \mu \mathrm{g} \cdot \mathrm{mL}^{-1}$, $\mathrm{BIS}=30$, and SEF $=12$. After induction, a duodecapolar catheter was inserted in the right internal jugular vein and placed inside the coronary sinus and the recording poles at the junction of the right atrium and superior vena cava. The right femoral vein was punctured twice for access of two sheaths for transeptal puncture. An intracardiac ultrasound probe was placed in the right atrium through the left femoral vein. The decapolar circular catheter (Lasso) and the ablation catheter were placed in the left atrium through two intracardiac echocardiogram-guided transeptal punctures. Systemic heparinization associated with monitoring of the activated coagulation time (ACT > $300 \mathrm{sec}$.) was instituted. The Lasso catheter was used for electrical mapping of the pulmonary veins. The pulmonary veins were disconnected from the left atrium by applying 30-watt radiofrequency with an irrigated catheter. Target-controlled infusion of propofol and remifentanil using infusion pumps with pharmacokinetic systems for each of the drugs was administered. We used the pharmacokinetic model described by Marsh for propofol, which was incorporated into the propofol PFS ${ }^{\circledR}$ pump. The pharmacokinetic model described by Minto for remifentanil was used and incorporated into the Alaris $\mathrm{PK}^{\circledR}$ infusion pump. The concentration at the effector site, or biophase, corresponded to the information obtained through the infusion pumps and represented the predictive concentrations of both drugs at their sites of action. The concentrations of propofol and remifentanil were regulated according to BIS and MAP, respectively. Anesthesia was maintained with $\mathrm{TCl}$ of propofol at adequate concentrations to maintain BIS between 40 and 50 . The mean arterial pressure and $\mathrm{HR}$ remained within normal limits during the procedure. The maximal and minimal concentrations of propofol at the effector site were 2.5 and $1.9 \mu \mathrm{g} \cdot \mathrm{mL}^{-1}$, respectively. Remifentanil was titrated to maintain a maximal $20 \%$ variation in MAP. The maximal and minimal concentrations of remifentanil at the effector site were 4 and 2 ng. $\mathrm{mL}^{-1}$, respectively. The total propofol and remifentanil infusion time was 300 minutes. A mean infusion rate of $4.6 \mathrm{mg} \cdot \mathrm{kg}^{-1} \cdot \mathrm{h}^{-1}$ of propofol was used, while that of remifentanil was $0.1 \mu \mathrm{g} \cdot \mathrm{kg}^{-1} \cdot \mathrm{h}^{-1}$. Total doses of propofol of 1,697 $\mathrm{mg}$ and remifentanil of $2 \mathrm{mg}$ were used. The initial MAP was $80 \mathrm{mmHg}$ and it was maintained between 65 and $80 \mathrm{mmHg}$ during the procedure with the administration of intravenous boluses of vasopressors in only two occasions. An esophageal thermometer was placed to determine the esophageal temperature when radiofrequency was applied close to the esophagus. The infusions of remifentanil and propofol were discontinued at the end of the procedure. The patient was extubated when the concentration of propofol at the effector site reached $1.2 \mu \mathrm{g} \cdot \mathrm{mL}^{-1}$ and she was on sinus rhythm, and with stable vital signs and spontaneous ventilation after reversal of the neuromuscular blockade. The patient was then transferred to the post anesthetic care unit.

\section{DISCUSSION}

Ablation of intracardiac anomalous pathways is a relatively common procedure among us. It is more commonly performed under local anesthesia associated with several se- 
dation techniques. The national literature does not have reports on anesthetic alternatives for ablation of AF. The objective of this report was to present alternatives and suggestions of general anesthesia for ablation of AF. Unlikely ablations of supraventricular tachycardia, ablation of $A F$ is a more complex procedure involving anticoagulation, central venous punctures in several locations, insertion of multiple catheters and thermometers, urinary catheter, and multiplechannel monitoring. For those reasons, we decided to use general anesthesia with tracheal intubation. Cohen et al. described, in a comparative study between inhalational general anesthesia with isoflurane and total intravenous anesthesia with propofol in pediatric patients undergoing ablation of supraventricular tachycardia, higher induction times of supraventricular tachycardia and doses of isoproterenol to induce supraventricular tachycardia in the group of patients anesthetized with isoflurane ${ }^{1}$. Another study by Herman et al. reported on the safety of isoflurane in patients with supraventricular tachycardia ${ }^{2}$. Enflurane, halothane, and isoflurane seem to increase the refractory period of anomalous pathways, as well as that of the normal atrioventricular conduction system and, therefore, the use of those drugs in anesthesia for ablation of anomalous pathways is contraindicated ${ }^{3}$. By increasing the refractory period of the atria, those inhalational agents can cause false ablation results. It seems that sevoflurane does not affect atrial conduction pathways representing an alternative when general inhalational anesthesia is chosen ${ }^{4}$. But it decreases the conduction time of the sinoatrial node and the conduction interval between the atria and the Hiss bundles, although those changes have little clinical repercussion during the administration of up to 1 MAC of sevoflurane, according to Sharpe et al. ${ }^{4}$ The literature also has reports on intravenous anesthetics, such as sufentanil, alfentanil, midazolam, and propofol, and they do not seem to change the electrophysiological properties of anomalous or normal atrioventricular conduction pathways ${ }^{3,5,6}$. We decided to use total intravenous anesthesia with propofol and remifentanil due to the need of early arousal, low possibility of changing atrial excitability threshold, and low intensity of painful stimuli during the procedure ${ }^{6}$. During induction, in which the infusions of remifentanil and propofol were instituted simultaneously, as described by Nora et al., a $20 \%$ reduction in MAP was observed ${ }^{8}$. The mean arterial pressure returned to normal after tracheal intubation without the need of vasopressors. We did not find reports in the literature on the use of remifentanil in ablation of anomalous bundles, although the use of other opioids such as alfentanil is supported ${ }^{5}$. Extreme care should be used when choosing the anesthetic technique to avoid changing the electrical patterns of intracardiac conduction bundles. Total intravenous anesthesia allowed early neurological assessment. The low doses of the propofol and especially,remifentanil infusions were striking, since they were lower than described in the literature for general anesthesia ${ }^{7}$. Several factors might be responsible for this reduction in the dose of remifentanil, such as the nature of the procedure, patient-related characteristics, premedication, and use of TCI. Propofol and remifentanil were chosen because these agents do not seem to induce changes in the results of intracardiac mapping and can constitute a good choice for the proposed procedure. As for monitoring, the use of BIS was important because it allowed adequate and safe titration of propofol, and it is possible that this monitor was important in determining a reduction in the infusion doses of propofol to rates below 6 $\mathrm{mg} \cdot \mathrm{kg}^{-1} \cdot \mathrm{h}^{-1}$. Similarly, the use of $\mathrm{TCl}$ of intravenous drugs allowed more judicious titration through constant changes in plasma concentration according to the variations of BIS and MAP, since monitoring of the HR is not reliable due to the nature of the procedure. Patient-related characteristics, as well as premedication with midazolam, might have contributed for the low doses of anesthetics, making it impossible to state that BIS alone was responsible for this. It is important to emphasize the need of postoperative analgesia since pain severity associated with this procedure varies, and it can be initially high due to pericardial irritation. Ablation of $\mathrm{AF}$ is performed outside of the surgical center and can be safely conducted under total intravenous anesthesia and tracheal intubation. More conclusive publications on the safest anesthesia technique in this situation are rare, although most have mentioned the importance of using drugs that do not change the electrophysiology of the cardiac conduction tissue and accessory pathways involved in the maintenance of AF. Any drugs that change the electrophysiological expression of accessory pathways might interfere with the localization and subsequent assessment of the ablation results. Target-controlled infusion of intravenous drugs monitored with BIS and MAP facilitated maintenance of satisfactory anesthetic plane and influenced, among other aspects, the doses used, which might reduce costs. Targetcontrolled infusion in total intravenous anesthesia for ablation of AF can become an attractive alternative since it allows fast awakening that facilitates immediate neurologic evaluation. The publication of more encompassing clinical assays may or may not ratify this anesthetic choice.

\section{REFERÊNCIAS - REFERENCES}

01. Cohen IT, Furbush N, Moak J - Propofol infusions for radiofrequency catheter ablation for supraventricular tachycardia in children. Anesth Analg, 1999;88(2/suppl):s291.

02. Hermann R, Vettermann $\mathrm{J}$ - Change of ectopic supraventricular tachycardia to sinus rhythm during administration of propofol Anesth Analg, 1992;75:1030-1032.

03. Sharpe MD, Dobkowski WB, Murkin JM et al. - The electrophysiologic effects of volatile anesthetics and sufentanil on the normal atrioventricular conduction system and accessory pathways in Wolff-Parkinson-White syndrome. Anesthesiology, 1994; 80:63-70.

04. Sharpe MD, Cuillerier DJ, Lee JK et al. Sevoflurane has no effect on sinoatrial node function or on normal atrioventricular and accessory pathway conduction in Wolff-Parkinson-White syndrome during alfentanil/midazolam anesthesia. Anesthesiology, 1999;90:60-65. 
05. Sharpe MD, Dobkowski WB, Murkin JM et al. - Alfentanil-midazolam anaesthesia has no electrophysiological effects upon the normal conduction system or accessory pathways in patients with Wolff-Parkinson-White syndrome. Can J Anaesth, 1992;39:816-821.

06. Sharpe MD, Dobkowski WB, Murkin JM et al. - Propofol has no direct effect on sinoatrial node function or on normal atrioventricular and accessory pathway conduction in Wolff-ParkinsonWhite syndrome during alfentanil/midazolam anesthesia. Anesthesiology, 1995;82:888-895.

07. Nora FS - Anestesia venosa total em regime de infusão alvo controlada. Uma análise evolutiva. Rev Bras Anestesiol, 2008;58: 179-192.

08. Nora FS, Klipel R, Ayala G et al. - Remifentanil: o regime de infusão faz diferença na prevenção das respostas circulatórias à intubação traqueal? Rev Bras Anestesiol, 2007;57:247-260.

\section{RESUMEN}

Nora FS, Pimentel M, Zimerman LI, Saad EB - Anestesia Venosa Total con Infusión Objeto-Controlada de Remifentanil y Propofol para Ablación de la Fibrilación Atrial.

JUSTIFICATIVA Y OBJETIVOS: La ablación de fibrilación atrial (FA) es un procedimiento nuevo en nuestro medio, aunque sea común en otros centros. No han sido descritos la elección de la anestesia, los monitores y los cuidados anestesiológicos para ese procedimiento realizado fuera del bloque quirúrgico. El objetivo de este relato fue describir una técnica de anestesia para la realización de la ablación de FA.

RELATO DEL CASO: Paciente femenina, 49 años, $73 \mathrm{~kg}, 155 \mathrm{~cm}$, ASA I/ por hipertensión arterial sistémica. El monitoreo tuvo un electrocardiograma con 12 derivaciones, oximetría de pulso, frecuencia cardiaca, electroencefalografía bispectral para medidas de BIS, tasa de supresión (SR) y SEF95, y presión arterial promedio (PAM). La inducción anestésica fue realizada con propofol por vía venosa, en infusión objeto-controlada (IAC), con objeto regulado en $4 \mu \mathrm{g} \cdot \mathrm{mL}^{-1}$, remifentanil por vía venosa, en IAC, con objeto de 3 ng. $\mathrm{mL}^{-1}$, y rocuronio por vía venosa en bolo con dosis de $0,2 \mathrm{mg} \cdot \mathrm{kg}^{-1}$. El modelo farmacocinético de propofol utilizado fue el descrito por Marsh y fue incorporado a la bomba de propofol PFS ${ }^{\circledR}$. El modelo farmacocinético de remifentanil utilizado fue el descrito por Minto y fue incorporado a la bomba de infusión Alaris $P K^{\circledR}$. Las concentraciones en el local efector o biofase, correspondieron a informaciones obtenidas a través de las bombas de infusión, y representaron medidas de predicción de las concentraciones de los dos fármacos en los respectivos locales de acción. Las concentraciones de propofol y de remifentanil se regularon a tono con el $B I S$ y la PAM, respectivamente.

CONCLUSIONES: La anestesia venosa total para la ablación de FA, puede ser una opción segura si tenemos en cuenta que no hay alteración de la electrofisiología de las vías accesorias. La literatura es escasa en ese sentido, y nuevas publicaciones podrán o no justificar esa modalidad de anestesia durante la ablación de FA. 